\title{
EFFECT OF RESIDUE RETENTION, TILLAGE OPTIONS AND TIMING OF N APPLICATION IN RICE-WHEAT CROPPING SYSTEM
}

\author{
S. C. Tripathi", S. Chander and R. P. Meena \\ Directorate of Wheat Research, P B No. 158, Karnal-132 001, Haryana, India
}

\begin{abstract}
A field experiment was conducted at the research farm of the Directorate of Wheat Research, Karnal (Haryana) during 2007-08 to 2009-10 with the objective to compare the whole basal and split application of nitrogen under different residue management and tillage options in rice-wheat cropping system. Combined analysis of data revealed that puddled transplanted rice produced maximum rice grain yield, straw yield, thousand grain weight and grains /panicle. Rice yield under zero tillage was decreased to the tune of $27.8 \%$ (with residue), $33.9 \%$ (without residue) and $45.3 \%$ (under permanent bed planting) as compared to puddled transplanted condition. Split application of nitrogen increased the rice grain yield to the extent of $4.7 \%$ with residue, $8.0 \%$ without residue and $10.2 \%$ under puddled transplanted condition as compared to whole basal $\mathrm{N}$ application. Pooled analysis under zero tillage condition, retention of rice residue enhanced the wheat grain yield $21.3 \%$ at zero $\mathrm{N}$, $8.3 \%$ at $150 \mathrm{~N}$ (whole basal) and $5.4 \%$ at $150 \mathrm{~N}$ (three split) applications. Application of nitrogen in three split doses increased the wheat grain yield up to $9.6 \%$ without residue retention and $6.7 \%$ with rice residue retention condition as compared to whole basal $\mathrm{N}$ application. In nut shell, it can be said that adoption of zero tillage, residue retention and whole basal $\mathrm{N}$ application did not work well for rice whereas it was better for wheat in rice-wheat system.
\end{abstract}

Keywords: Bed planting, Economics, nitrogen, Organic carbon, Residue

retention, Rice-wheat, Yield, Zero tillage

\section{INTRODUCTION}

In South Asia, rice-wheat crop sequence is the largest agriculture production system and occupies about 13.5 million hectares area including 10 million hectares in India, extending from Indo-Gangetic plain to Himalayan foothills. Rice and wheat contribute $80 \%$ of total cereal production in the region. In India, approximately $23 \%$

\footnotetext{
*Corresponding author email: subhtripathi@gmail.com
} 
and $40 \%$ of total rice and wheat area, respectively, is represented by rice-wheat system alone (Timsina and Connor, 2001), which requires contrasting edaphic conditions. Rice is generally transplanted in puddled soil and is grown under submerged condition whereas wheat is grown in upland well-drained soils having good tilth. Rice-wheat crop sequence that yield $7 \mathrm{tha}^{-1}$ of rice and $4 \mathrm{t} \mathrm{ha}^{-1}$ wheat removes more than $300 \mathrm{~kg} \mathrm{~N}, 30 \mathrm{~kg} \mathrm{P}$ and $300 \mathrm{~kg} \mathrm{~K} \mathrm{ha}^{-1}$ from the soil. Continuous adoption of this system has been reported to decline soil and crop productivity (Nambiar and Abrol, 1989). Analysis of several long-term experiments on rice-wheat system (Dawe et al., 2000, Duxbury et al., 2000 and Yadav et al., 1998) indicated a negative average yield trend of rice $\left(-0.02 \mathrm{t} \mathrm{ha}^{-1} \mathrm{yr}^{-1}\right.$ or $\left.0.5 \% \mathrm{yr}^{-1}\right)$ under fixed set of inputs and agronomic practices.

Conservation agriculture requires three things, namely no tillage, residue retention and cropping system. Residue burning is the main problem under ricewheat system in North West Plain Zone of India. To address this issue an experiment was planned with tillage options (zero tillage, bed planting and conventional tillage), residue retention/incorporation in rice as well as in wheat and application of nitrogen (whole quantity as basal v/s three splits) under rice-wheat system.

\section{MATERIALS AND METHODS}

A field experiment was conducted in rice-wheat cropping system during 2007 08 to 2009-10 at research farm of the Directorate of Wheat Research, Karnal (Latitude $29^{\circ} 43^{\prime} \mathrm{N}$, longitude $76^{\circ} 58^{\prime} \mathrm{E}$ and altitude $245 \mathrm{~m}$ ). Twelve treatments viz., $\mathrm{T}_{1}$. Zero tillage with $0 \mathrm{~N}, \mathrm{~T}_{2}$. Zero tillage with $150 \mathrm{~N}$ basal, $\mathrm{T}_{3}$. Zero tillage with $150 \mathrm{~N}$ split (3), $\mathrm{T}_{4}$. Zero tillage with $0 \mathrm{~N}$ +residue retention on surface, $\mathrm{T}_{5}$. Zero tillage with $150 \mathrm{~N}$ basal +residue retention on surface, $\mathrm{T}_{6}$. Zero tillage with $150 \mathrm{~N}$ split + residue retention on surface, $\mathrm{T}_{7}$. Bed planting with $150 \mathrm{~N}$ split, $\mathrm{T}_{8}$. Bed planting with $150 \mathrm{~N}$ basal + residue retention on surface, $\mathrm{T}_{9}$. Bed planting with $150 \mathrm{~N}$ split + residue retention on surface, $\mathrm{T}_{10}$. Conventional tillage with $150 \mathrm{~N}$ split +residue incorporated, $\mathrm{T}_{11}$. Conventional tillage with $150 \mathrm{~N}$ basal, $\mathrm{T}_{12}$. Conventional tillage with $150 \mathrm{~N}$ split, were conducted in randomized block design and replicated thrice. Residue of rice and wheat crop was retained or incorporated @ $6 \mathrm{t} \mathrm{ha}^{-1}$ and $\mathrm{N}$ was applied as per respective treatments followed by irrigation. Rice variety Govind was direct seeded in 1st week of June and 25 days old seedlings were transplanted in puddled condition in first week of July. Wheat variety PBW 502 was seeded after rice harvest in zero tillage and conventional tillage conditions. Fertilizers @ $150 \mathrm{~kg} \mathrm{~N}$, $60 \mathrm{~kg} \mathrm{P}_{2} \mathrm{O}_{5}$ and $40 \mathrm{~kg} \mathrm{~K}_{2} \mathrm{O} \mathrm{ha}^{-1}$ were applied to the rice and wheat crop as per treatment. Full dose of phosphorous in the form of single super phosphate and potash in the form of muriate of potash and one third dose of nitrogen in the form of urea was applied as basal i.e., before sowing and remaining two third dose of nitrogen was top dressed in two equal splits at first node stage (DC 31, DC stands for Decimal Code of Zadoks scale ranging from 0 to 99) (Zadoks et al., 1974) and at booting stage (DC 41). Irrigation was applied as per need of the crop. Weeds in zero till rice were controlled 
with the application of pendimethyline @1.0 kg ha ${ }^{-1}$ just after seeding whereas in transplanted rice weeds were controlled with the application of butachlor @ $1.0 \mathrm{~kg} \mathrm{ha}^{-1}$ in 400 litre of water at 3-4 days after rice transplanting. Similarly weeds in wheat were controlled with the application of sulfosulfuron @ $25 \mathrm{~g} \mathrm{ha}^{-1}$ in 400 liters of water at 3035 days after sowing. All the other recommended practices were adopted in rice as well as in wheat. Observations were recorded on yield and its component characters and soil analysis, mainly organic carbon, electrical conductivity and $\mathrm{pH}$ were done at the start and end of the experiment. Standard statistical methods of analysis were followed for the yield and yield attributing parameters and soil analysis (Gomez and Gomez, 1984). Cost of cultivation was calculated by taking into account the prevailing price of inputs like fertilizer, seed, herbicides, irrigations, tillage operations, transportation charges, management charges, rental value of land and depreciation cost of implements. Returns were calculated by taking minimum support price of rice and wheat grain yield and market price of rice and wheat straw on pooled yield basis.

\section{RESULTS}

\section{Rice yield}

All the parameters like grain yield, straw yield, harvest index (HI), 1000-grain weight, panicles $/ \mathrm{m}^{2}$ and grains/panicle were significant for yearly as well as combined analysis over the years. Pooled analysis of data (Tables 1 and 2) revealed that puddled transplanted rice (T10 to T12) produced maximum rice grain yield, straw yield, thousand grain weight and grains /panicle. Direct seeded zero till rice was decreased to the tune of $27.8 \%$ (with residue), $33.9 \%$ (without residue) and $45.3 \%$ (under permanent bed planting) as compared to puddled transplanted condition. There was lesser decrease in rice yield where wheat residue was retained on the surface under residue retention treatments $\left(\mathrm{T}_{5}\right.$ and $\left.\mathrm{T}_{6}\right)$ suggesting beneficial effect of wheat residue on rice yield. Split application of nitrogen increased the rice grain yield to the extent of $4.7 \%$ with residue, $8.0 \%$ without residue and $10.2 \%$ under puddled transplanted condition as compared to whole basal $\mathrm{N}$ application. Therefore, split $\mathrm{N}$ application under zero tillage with and without residue retention condition holds better for rice crop as compared to whole basal $\mathrm{N}$ application.

Residue retention under zero tillage condition enhanced the rice grain yield by $9.2 \%$ with zero $\mathrm{N}$ and $8.4 \%$ with $150 \mathrm{~kg} \mathrm{~N} \mathrm{ha}^{-1}$ application as compared to respective no residue retention treatments. This suggests that there was positive role of wheat residue in increasing rice yield as compared to without residue condition. Maximum and significantly higher straw yield $\left(13.0 \mathrm{t} \mathrm{ha}^{-1}\right)$ and HI (0.40) was recorded in puddled transplanted with split $\mathrm{N}$ application treatment. Under puddled transplanted condition, thousand grain weight and grains/panicle was maximum and significantly higher than all other treatments. However, there was no such difference in case of panicles $\mathrm{m}^{-2}$. Direct seeded rice either under zero tillage or under bed planting (bed planting means raised surface $40 \mathrm{~cm}$ and furrow $30 \mathrm{~cm}, 3$ rows on top of bed i.e. on 
raised surface, furrow to furrow distance $70 \mathrm{~cm}$ ) produced significantly lower thousand grain weight and grains/panicle than puddled transplanted condition. This shows that rice grain yield under puddled transplanted condition was higher due to significantly higher thousand grain weight and grains/panicle. There was variation in rice yield during period of study and maximum grain yield was recorded in 2008 . During crop cycle 2008, thousand grain weight and grains/panicle was maximum in all the treatments as compared to 2007 or 2009 crop cycle.

\section{Wheat yield}

All the parameters like grain yield, straw yield, HI, 1000 grain weight, panicles $\mathrm{m}^{-2}$ and grains per panicle were significant for yearly as well as across the year analysis (Tables 3 and 4). Pooled analysis under zero tillage condition, retention of rice residue enhanced the wheat grain yield $21.3 \%$ at zero $\mathrm{N}, 8.3 \%$ at $150 \mathrm{~N}$ (whole basal) and $5.4 \%$ at $150 \mathrm{~N}$ (three split) applications as compared to without residue condition. Three split application of $150 \mathrm{~N}$ under rice residue on surface with zero tillage produced similar yield $\left(5.83 \mathrm{t} \mathrm{ha}^{-1}\right)$ as compared to conventional tillage condition (5.54 to $5.83 \mathrm{t} \mathrm{ha}^{-1}$ ) condition. As compared to whole basal $\mathrm{N}$ application, grain yield increased in split application of $\mathrm{N}$ was due to significantly higher grains/ear head (11.2\% without residue and $13.5 \%$ with residue condition). Therefore, it could be said that increase in grain yield under split $\mathrm{N}$ application with and without residue retention condition was mainly attributed by increase in grains/spike. At zero $\mathrm{N}$ application, residue retention increased the grains spike ${ }^{-1}$ to the tune of $14.5 \%$. Straw yield was maximum $\left(8.52 \mathrm{t} \mathrm{ha}^{-1}\right)$ under conventional tillage with whole basal $\mathrm{N}$ application $\left(150 \mathrm{~kg} \mathrm{ha}^{-1}\right)$ and harvest index was maximum (0.47) with conventional tillage split $\mathrm{N}$ application (residue incorporation). There was no definite trend in case of thousand grain weight. Ear head $\mathrm{m}^{-2}$ was maximum (498) and significantly higher in conventional tillage with split $\mathrm{N}$ application as compared to other treatments.

\section{Organic carbon}

In general, organic carbon content, $\mathrm{pH}$ and $\mathrm{EC}$ were higher after three years of study in all the treatments (Table 6). Under zero tillage condition, residue retention with no nitrogen application increased the organic carbon to the extent of $14.2 \%$ as compared to without residue condition. Similarly residue retention at $150 \mathrm{~kg} \mathrm{~N} / \mathrm{ha}$ application increased organic carbon content 9.3 to $13.9 \%$ as compared to without residue retention condition. Under bed planting condition residue retention enhanced the organic carbon content to the extent of $3.6 \%$ to $6.1 \%$ compared to no residue retention. Maximum $\mathrm{pH}$ and $\mathrm{EC}$ values were 8.16 and 0.518 , respectively after three years study.

\section{Economic Analysis}

In general, cost of rice cultivation was higher than cost of wheat cultivation (Table 5). Under zero tillage or permanent bed planting conditions, return from rice 
was lower than cost of rice cultivation, whereas in case of puddled transplanted condition it was just reverse. Total cost of cultivation and total return were maximum under puddled transplanted rice followed by conventionally tilled wheat. Net return at zero $\mathrm{N}$ application and permanent bed planting condition of rice-wheat cropping was negative. This showed that these technologies are not feasible under no till conditions. Positive net return and $\mathrm{B}: \mathrm{C}$ ratio more than one in case of puddled transplanted rice followed by conventional till wheat and zero tilled rice-wheat with and without residue retention were profitable. Benefit accrued by adoption of zero tillage for eco friendly cultivation and improvement in soil health was not included in the economics of different treatments.

\section{DISCUSSION}

Conservation agriculture (adoption of zero tillage with residue retention in a cropping system perspective) has emerged as a major strategy to achieve goals of sustainable agriculture. No-tillage when combined with surface managed crop residues sets in motion processes whereby slow decomposition of residues results in improvement in soil health. Rice yield under no till system declined drastically (27.8$45.3 \%$ ). These findings were against the observation of Kumar et al. (2005), who reported similar yield by adopting conservation practices. Sah et al. (2013) also reported higher rice yield with residue retention which is in contrast to our findings. In Haryana, where soils are sandy loam, it can be said that adoption of residue retention and whole basal $\mathrm{N}$ application are not suitable for rice in rice-wheat system. In wheat crop, three splits application of nitrogen increased the grain yield up to 9.6 $\%$ without residue retention and $6.7 \%$ with rice residue retention condition as compared to whole basal $\mathrm{N}$ application. These findings were in agreement with observation of Kharub and Chander (2010). Naresh et al. (2013) also reported that split application of nitrogen increased wheat yield under residue retention condition. Permanent bed planting treatments recorded lowest wheat grain yield (4.96 to $5.02 \mathrm{t}$ $\left.\mathrm{ha}^{-1}\right)$. This finding is in contrast to the observations of Hobbs and Gupta (2003a) under rice-wheat system. Economics play an important role in the adoption of technologies. Positive net return and $\mathrm{B}: \mathrm{C}$ ratio more than one in case of zero tilled rice- wheat with and without residue retention were profitable and provides ecofriendly cultivation. Residue retention enhanced the organic carbon content of soil as compared to residue removal which was in agreement with observations of Naresh (2013). However, there was no significant difference between residue retention and residue incorporation for the organic carbon content. This finding was in agreement with observations of Ladha et al. (1986).

\section{CONCLUSION}

Puddled transplanted rice produced maximum rice grain yield, straw yield, thousand-grain weight and grains /panicle. Rice yield under zero tillage decreased to the tune of $27.8 \%$ (with residue), $33.9 \%$ (without residue) and $45.3 \%$ (under 
permanent bed planting) as compared to puddled transplanted condition. Application of nitrogen in three split doses increased the rice grain yield to the extent of $4.7 \%$ with residue, $8.0 \%$ without residue and $10.2 \%$ under puddled transplanted condition as compared to whole basal $\mathrm{N}$ application. Rice residue retention enhanced the wheat grain yield $21.3 \%$ under zero N, 8.3\% $150 \mathrm{~N}$ (whole basal) and $5.4 \%$ under $150 \mathrm{~N}$ (three split) applications. Promoting conservation agriculture in rice-wheat system will call for moving away from the conventional compartmentalized and hierarchical arrangement of research that generated and perfected technologies, extension that delivers it and farmers who adopt it. All the stakeholders involved would need to be brought together on a common platform to conceive end-to-end strategies. Roles of research, extension, farmers and other stakeholders should be institutionalized in a way that strengthens these partnerships.

\section{REFERENCES}

Dawe, D., Dobermann, A., Moya, P., Abdul Rachhman, S., Lal, P., Li ,S.Y., Lin, B., Panaullah, G., Sariam, O., Singh, Y., Swarup, A., Tan, P.S. and Zhen, Q.X. 2000. How widespread are yield declines in long-term rice experiments in Asia? Field Crops Research, 66:175-193

Duxbury, J. M., Abrol, I.P., Gupta, R.K. and Bronson, K.F. 2000. Analysis of long-term soil fertility experiments with rice-wheat rotations in South Asia. In I.P. Abrol et al. (ed.) Long-term soil fertility experiments with rice-wheat rotations in South Asia. RiceWheat Consortium Paper Series No 6. Rice-Wheat Consortium for Indo Gangetic Plains, New Delhi, India. P.vii-xxii

Gomez, K. A. and Gomez, A. A. 1984. Statistical Procedures for Agricultural Research, pp 97107. John Willey \& Sons, New York

Hobbs, P. R. and Gupta, R. K. 2003a. Resource-conserving technologies for wheat in the ricewheat system. In: Improving Productivity and Sustainability of Rice-Wheat Systems: Issues and Impact. American Society of Agronomy, Special. Publ. 65, 149-171

Kharub, A. S. and Chander Subhash. 2010. Effect of nitrogen scheduling on wheat (Triticum aestivum) productivity and quality under alternate tillage practices. Indian Journal of Agricultural Sciences, 80 (1):29-32

Kumar, Sandeep, Pandey, D. S., Rana, N. S. 2005. Economics and yield potential of wheat (Triticum aestivum) as affected by tillage, rice (Oryza sativa) residue and nitrogen management options under rice-wheat system. Indian Journal of Agronomy, 50 (2): $102-105$

Ladha, J.K., Tirol, A.C., Daroy, M.L.G., Caldo, G., Ventura, W.,Watanabe, I. 1986. Plant associative $\mathrm{N}_{2}$ fixation $\left(\mathrm{C}_{2} \mathrm{H}_{2}\right.$ reduction) by rice varieties and relationship with plant growth characters as affected by straw incorporation. Soil Science and Plant Nutrition, 32: 91-106

Nambiar, K. K. M. and Abrol, I .P .1989. Long term fertilizer experiments in India. An overview-Fertilizer News, 34: 11-20 
Naresh, R. K. 2013. Rice residues: From waste to wealth through environment friendly and innovative management solutions, its effects on soil properties and crop productivity. International Journal of Life Sciences Biotechnology and Pharma Research, 2(1):133141

Naresh, R. K., Singh, S.P., Kumar, Deepesh and Pratap, Bhanu. 2013. Experience with managing rice residues in intensive rice-wheat cropping system in North-Western India.. International Journal of Life Sciences Biotechnology and Pharma Research, 2 (2):85-96

Sah, G., Shah, S.C., Sah, S.K., Thapa, R.B., McDonald, A., Sidhu, H.S., Gupta, R.K. and Wall, P. 2013. Agronomy Journal of Nepal, 3:64.72

Timsina, J. and Connor, D.J. 2001. The productivity and management of rice-wheat cropping systems: Issues and challenges. Field Crops Research, 69:93-132

Yadav, R.L., Prasad, K. and Gangwar, K.S. 1998. Analysis of ecoregional production constraints in rice-wheat cropping system. PDCSR Bull 98-2. Project Directorate on Cropping Systems Research, Modipuram, India

Zadoks, J.C., Chang, T.T. and Konzak, C.F. 1974. A decimal code for growth stages of cereals. Weed Research, 14:415-421 
Table 1. Effect of residue retention, tillage options and timing of $\mathrm{N}$ application on rice grain yield, straw yield and $\mathrm{HI}$

\begin{tabular}{|c|c|c|c|c|c|c|c|c|c|c|c|c|}
\hline \multirow[t]{2}{*}{ Treatments } & \multicolumn{4}{|c|}{ Grain Yield (t ha $\left.{ }^{-1}\right)$} & \multicolumn{4}{|c|}{ Straw Yield (t ha $\left.{ }^{-1}\right)$} & \multicolumn{4}{|c|}{ HI } \\
\hline & $\begin{array}{c}2007- \\
08\end{array}$ & $\begin{array}{c}\text { 2008- } \\
09\end{array}$ & $\begin{array}{c}2009- \\
10\end{array}$ & Pooled & $\begin{array}{c}\text { 2007- } \\
08\end{array}$ & $\begin{array}{c}\text { 2008- } \\
09\end{array}$ & $\begin{array}{c}2009- \\
10\end{array}$ & Pooled & $\begin{array}{c}\text { 2007- } \\
08\end{array}$ & $\begin{array}{c}2008- \\
09\end{array}$ & $\begin{array}{c}2009- \\
10\end{array}$ & Pooled \\
\hline $\mathrm{T}_{1}$ & 2.49 & 4.03 & 2.99 & 3.17 & 8.70 & 7.28 & 4.15 & 6.71 & 0.22 & 0.35 & 0.42 & 0.33 \\
\hline $\mathrm{T}_{2}$ & 3.98 & 5.74 & 4.11 & 4.61 & 10.83 & 7.53 & 5.81 & 8.07 & 0.27 & 0.43 & 0.42 & 0.37 \\
\hline $\mathrm{T}_{4}$ & 3.15 & 4.07 & 3.27 & 3.50 & 7.18 & 6.64 & 4.27 & 6.03 & 0.31 & 0.38 & 0.44 & 0.37 \\
\hline $\mathrm{T}_{5}$ & 4.58 & 5.93 & 4.87 & 5.13 & 12.69 & 7.96 & 5.84 & 8.83 & 0.27 & 0.43 & 0.46 & 0.38 \\
\hline $\mathrm{T}_{6}$ & 4.68 & 6.48 & 4.99 & 5.38 & 16.67 & 8.39 & 6.91 & 10.66 & 0.22 & 0.44 & 0.42 & 0.36 \\
\hline $\mathrm{T}_{10}$ & 6.95 & 9.03 & 7.12 & 7.70 & 13.89 & 15.58 & 9.55 & 13.00 & 0.33 & 0.37 & 0.43 & 0.38 \\
\hline $\mathrm{T}_{11}$ & 6.39 & 8.10 & 6.25 & 6.91 & 11.75 & 11.94 & 9.20 & 10.96 & 0.35 & 0.40 & 0.41 & 0.39 \\
\hline $\mathrm{T}_{12}$ & 6.89 & 7.87 & 6.95 & 7.24 & 10.46 & 13.08 & 9.20 & 10.91 & 0.39 & 0.38 & 0.43 & 0.40 \\
\hline $\mathrm{CD}(\mathrm{P}=0.05)$ & 0.66 & 0.73 & 0.86 & 0.45 & 0.82 & 0.96 & 1.02 & 0.65 & 0.04 & 0.06 & 0.07 & 0.04 \\
\hline
\end{tabular}


Table 2. Effect of residue retention, tillage options and timing of $\mathrm{N}$ application on rice yield attributes

\begin{tabular}{|c|c|c|c|c|c|c|c|c|c|c|c|c|}
\hline \multirow[t]{2}{*}{ Treatments } & \multicolumn{4}{|c|}{1000 Grain wt (g) } & \multicolumn{4}{|c|}{ Panicles $\mathbf{m}^{-2}$} & \multicolumn{4}{|c|}{ Grains panicle $^{-1}$} \\
\hline & $\begin{array}{c}2007- \\
08\end{array}$ & $\begin{array}{c}2008- \\
09\end{array}$ & $\begin{array}{c}2009- \\
10\end{array}$ & Pooled & $\begin{array}{c}2007- \\
08\end{array}$ & $\begin{array}{c}2008- \\
09\end{array}$ & $\begin{array}{c}2009- \\
10\end{array}$ & Pooled & $\begin{array}{c}\text { 2007- } \\
08\end{array}$ & $\begin{array}{c}2008- \\
09\end{array}$ & $\begin{array}{c}2009- \\
10\end{array}$ & Pooled \\
\hline $\mathrm{T}_{1}$ & 19.73 & 19.87 & 21.29 & 20.29 & 370 & 330 & 388 & 363 & 35.0 & 61.7 & 37.1 & 44.6 \\
\hline $\mathrm{T}_{2}$ & 20.88 & 21.60 & 21.39 & 21.29 & 358 & 423 & 398 & 393 & 53.0 & 62.9 & 48.2 & 54.7 \\
\hline $\mathrm{T}_{3}$ & 21.55 & 22.02 & 21.24 & 21.60 & 398 & 430 & 410 & 413 & 52.7 & 67.4 & 50.0 & 56.7 \\
\hline $\mathrm{T}_{4}$ & 19.73 & 19.87 & 21.29 & 20.29 & 360 & 372 & 383 & 372 & 45.3 & 61.6 & 40.6 & 49.2 \\
\hline $\mathrm{T}_{5}$ & 21.85 & 21.82 & 21.93 & 21.87 & 327 & 395 & 405 & 376 & 65.0 & 70.5 & 55.5 & 63.6 \\
\hline $\mathrm{T}_{6}$ & 21.52 & 21.02 & 22.15 & 21.56 & 373 & 393 & 423 & 397 & 60.0 & 80.7 & 53.3 & 64.7 \\
\hline $\mathrm{T}_{7}$ & 20.24 & 20.85 & 21.48 & 20.86 & 308 & 311 & 356 & 325 & 50.3 & 74.1 & 52.4 & 58.9 \\
\hline $\mathrm{T}_{8}$ & 20.29 & 21.12 & 21.57 & 20.99 & 295 & 307 & 391 & 331 & 53.7 & 67.6 & 45.8 & 55.7 \\
\hline $\mathrm{T}_{9}$ & 20.54 & 21.32 & 21.17 & 21.01 & 352 & 309 & 383 & 348 & 49.3 & 71.0 & 53.6 & 57.9 \\
\hline $\mathrm{T}_{10}$ & 27.36 & 31.10 & 22.77 & 27.08 & 305 & 368 & 413 & 362 & 84.0 & 78.9 & 75.8 & 79.5 \\
\hline $\mathrm{T}_{11}$ & 27.17 & 31.05 & 23.13 & 27.12 & 303 & 321 & 320 & 315 & 78.0 & 81.5 & 84.5 & 81.3 \\
\hline $\mathrm{T}_{12}$ & 27.84 & 32.17 & 23.09 & 27.69 & 305 & 418 & 377 & 367 & 82.0 & 60.7 & 79.9 & 74.2 \\
\hline $\mathrm{CD}(\mathrm{P}=0.05)$ & 1.56 & 1.28 & 1.16 & 0.78 & 24 & 33 & 37 & 26 & 15.1 & 13.4 & 13.5 & 9.6 \\
\hline
\end{tabular}


Table 3. Effect of residue retention, tillage options and timing of $\mathrm{N}$ application on wheat grain yield, straw yield and $\mathrm{HI}$

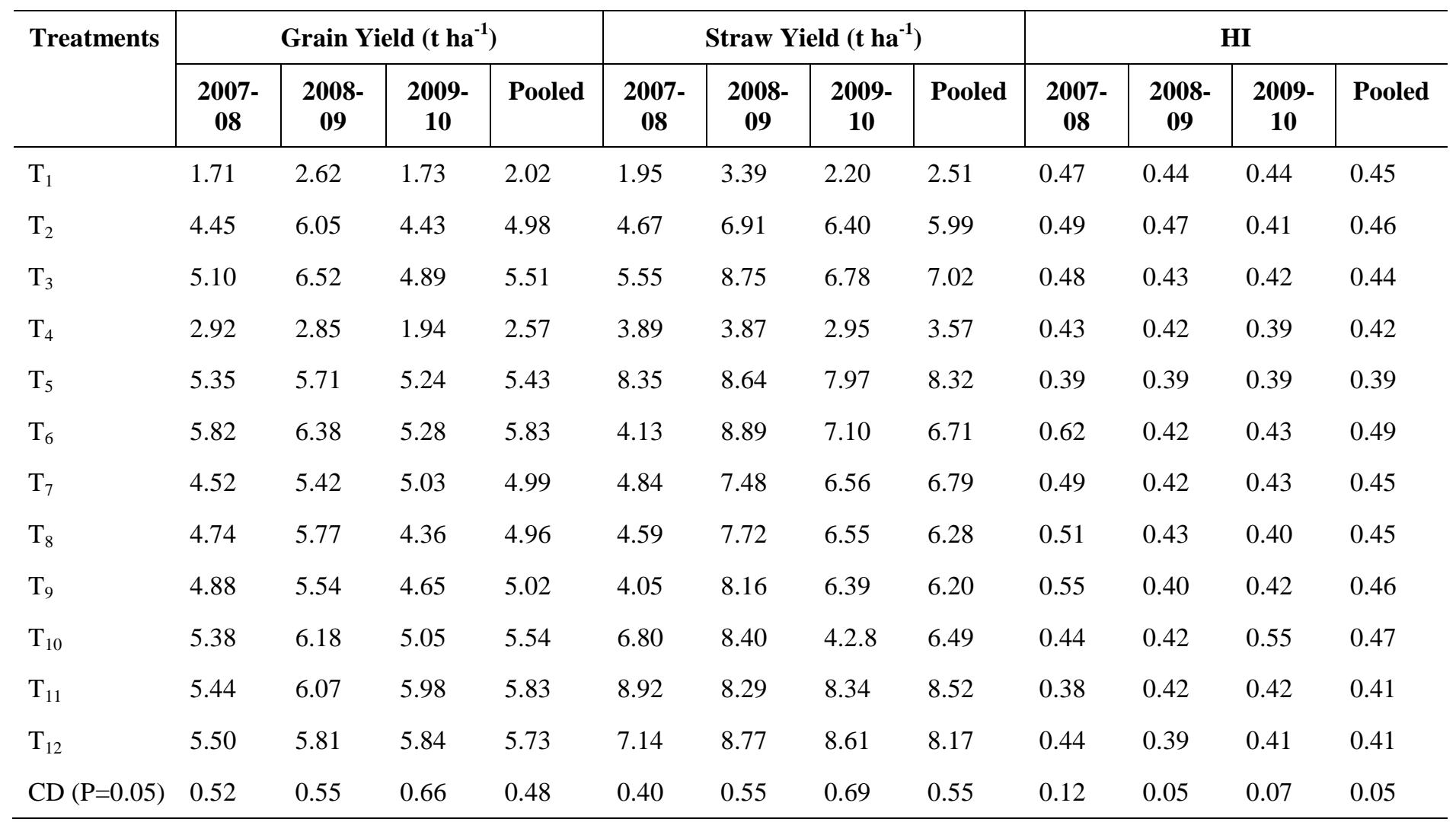


Table 4. Effect of residue retention, tillage options and timing of $\mathrm{N}$ application on wheat yield attributes

\begin{tabular}{|c|c|c|c|c|c|c|c|c|c|c|c|c|}
\hline \multirow[t]{2}{*}{ Treatments } & \multicolumn{4}{|c|}{1000 Grain wt (g) } & \multicolumn{4}{|c|}{ Ear head $\mathrm{m}^{-2}$} & \multicolumn{4}{|c|}{ Grains ear head $^{-1}$} \\
\hline & $\begin{array}{c}\text { 2007- } \\
08\end{array}$ & $\begin{array}{c}\text { 2008- } \\
09\end{array}$ & $\begin{array}{c}2009- \\
10\end{array}$ & Pooled & $\begin{array}{c}\text { 2007- } \\
08\end{array}$ & \begin{tabular}{|c}
$2008-$ \\
09
\end{tabular} & $\begin{array}{c}2009- \\
10\end{array}$ & Pooled & $\begin{array}{c}\text { 2007- } \\
08\end{array}$ & \begin{tabular}{|c}
$2008-$ \\
09
\end{tabular} & $\begin{array}{c}2009- \\
10\end{array}$ & Pooled \\
\hline $\mathrm{T}_{1}$ & 37.68 & 41.38 & 38.99 & 39.35 & 263 & 260 & 368 & 297 & 17.1 & 25.1 & 12.4 & 18.2 \\
\hline $\mathrm{T}_{2}$ & 41.07 & 42.43 & 41.43 & 41.64 & 335 & 435 & 457 & 409 & 32.4 & 34.3 & 23.6 & 30.1 \\
\hline $\mathrm{T}_{3}$ & 42.71 & 39.90 & 40.82 & 41.14 & 340 & 530 & 380 & 417 & 38.5 & 31.2 & 32.0 & 33.9 \\
\hline $\mathrm{T}_{4}$ & 39.53 & 43.36 & 39.49 & 40.79 & 300 & 252 & 368 & 307 & 24.2 & 26.4 & 13.4 & 21.3 \\
\hline $\mathrm{T}_{5}$ & 40.59 & 45.98 & 40.56 & 42.38 & 408 & 407 & 510 & 442 & 33.9 & 33.1 & 25.4 & 30.8 \\
\hline $\mathrm{T}_{6}$ & 42.25 & 40.43 & 42.75 & 41.81 & 362 & 413 & 380 & 385 & 38.5 & 39.1 & 29.3 & 35.6 \\
\hline $\mathrm{T}_{7}$ & 39.97 & 40.92 & 38.60 & 39.83 & 327 & 418 & 457 & 401 & 34.6 & 31.8 & 28.7 & 31.7 \\
\hline $\mathrm{T}_{8}$ & 40.02 & 44.32 & 41.32 & 41.89 & 300 & 411 & 463 & 392 & 39.7 & 31.7 & 22.9 & 31.5 \\
\hline $\mathrm{T}_{9}$ & 40.31 & 41.38 & 40.02 & 40.57 & 298 & 414 & 467 & 393 & 40.5 & 32.4 & 25.2 & 32.7 \\
\hline $\mathrm{T}_{10}$ & 40.75 & 39.81 & 41.58 & 40.72 & 467 & 350 & 417 & 411 & 28.7 & 45.2 & 30.1 & 34.7 \\
\hline $\mathrm{T}_{11}$ & 38.55 & 43.34 & 36.79 & 39.56 & 536 & 383 & 478 & 466 & 29.8 & 38.5 & 34.1 & 34.2 \\
\hline $\mathrm{T}_{12}$ & 40.49 & 37.92 & 37.29 & 38.57 & 588 & 358 & 547 & 498 & 23.1 & 47.1 & 28.9 & 33.0 \\
\hline $\mathrm{CD}(\mathrm{P}=0.05)$ & 2.12 & 2.03 & 3.51 & 1.95 & 26.4 & 33.7 & 35.1 & 28.0 & 4.8 & 5.1 & 4.7 & 3.0 \\
\hline
\end{tabular}


Table 5. Effect of residue retention, tillage options and timing of $\mathrm{N}$ application on economics of rice-wheat cropping system $\left(\mathrm{Rs} \mathrm{ha}^{-1}\right)$

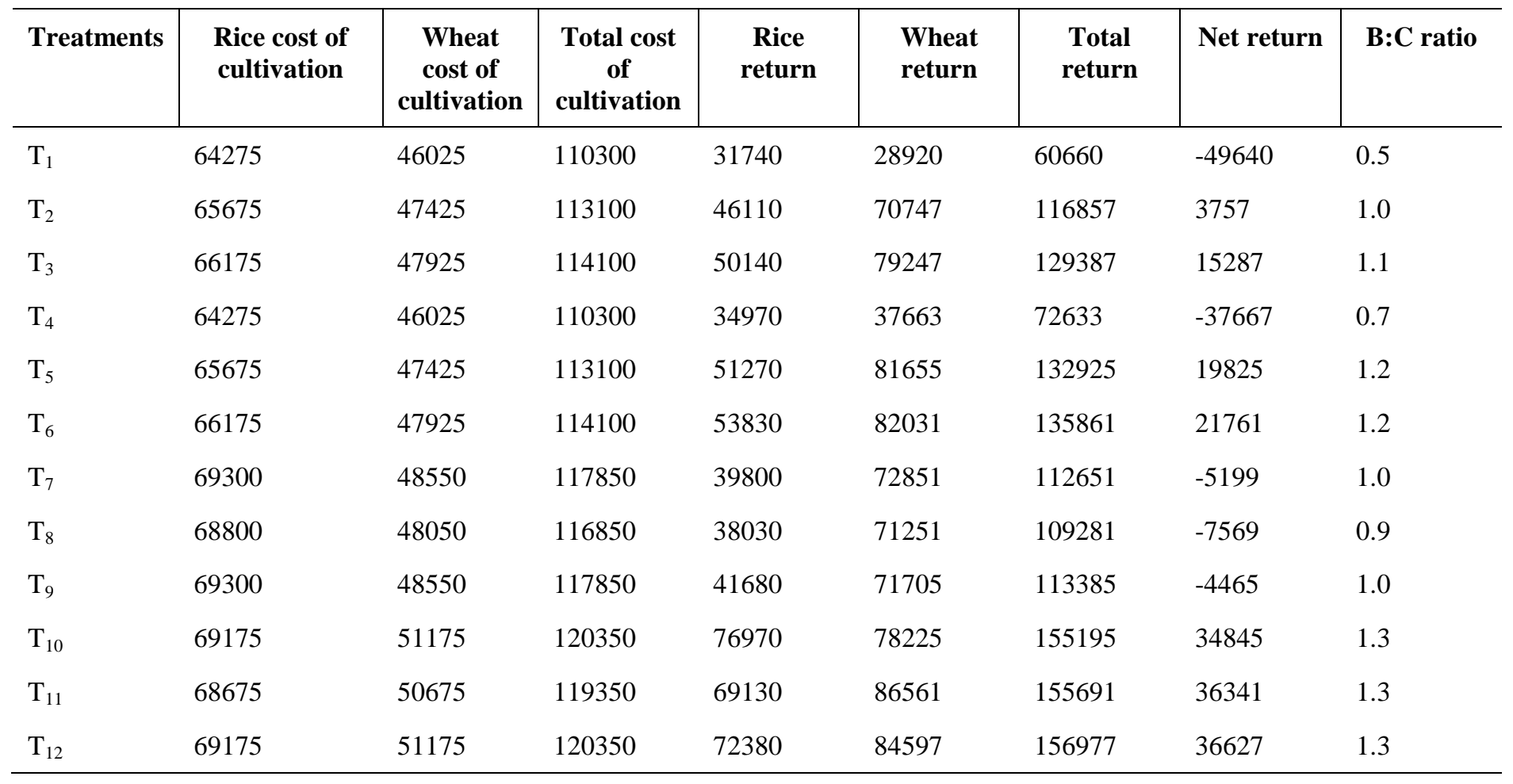


Table 6. Effect of residue retention, tillage options and timing of $\mathrm{N}$ application on organic carbon $(0-15 \mathrm{~cm}$ in $\%)$, $\mathrm{pH}$ and $\mathrm{EC}$

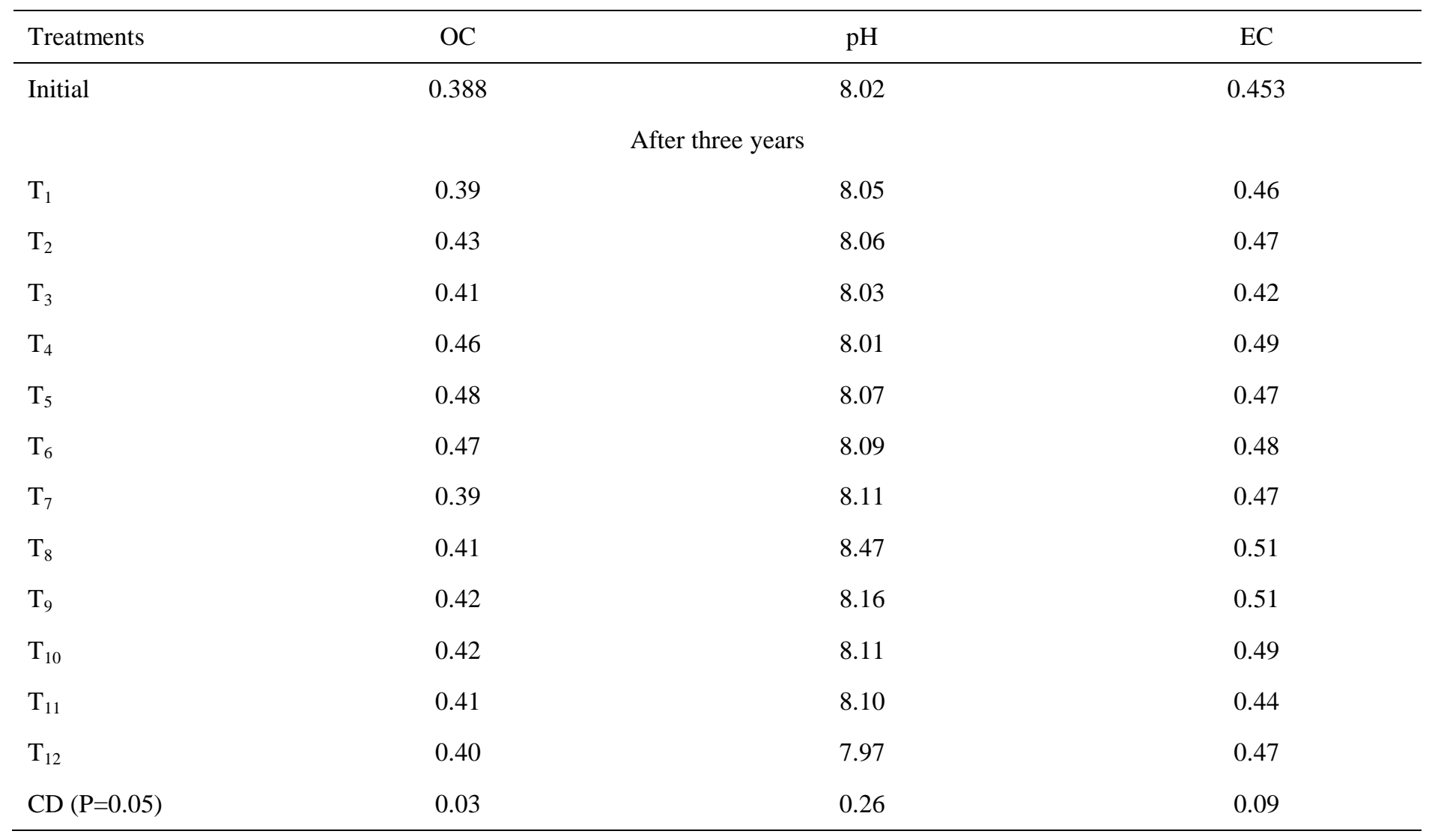

